11. Малинович Ю.М. Экспрессия и синтаксис художественного текста. Проблемы лингвистического анализа. 1980. С. 5-13.

12. Пасічник Г.П. Лексико-семантичні та структурні особливості тематично-описового дискурсу «природа»

у творах письменників 18 - поч. 20 ст. : дис. ... канд. фрілол. Наук : 10.02.04. Львів, 2005. 212 с.

13. Эпштейн М.Н. «Природа, мир, тайник вселенной...»: система пейзажних образов в русской поэзии. Москва : Высш. шк., 1990. 303 с.

14. Brown D. Angels and Demons. Croydon, Surrey: Bookmarque Ltd. 2003. 624 p.

15. Christie A. They Came to Baghdad [Audible Audio Edition]; narrated by Lisa Rae Campbell. Kyiv, 2004 ( 3 hrs and 27 mins).

16. Dickens Ch. The Christmas Books. London: Penguin Books, 1994. 234 p.

17. King S. The Green Mile. London: Penguin Books, 2007. 384 p.

УДК 808.51:328.131

DOI https://doi.org/10.32782/tps2663-4880/2019.12.13

\title{
PRAGMA-COMMUNICATIVE ASPECTS OF THE BORIS JOHNSONS' FIRST SPEECH AS A PRIME MINISTER (JULY 24, 2019)
}

\section{ПРАГМА-КОМУНІКАТИВНІ АСПЕКТИ ПЕРШОЇ ПРОМОВИ БОРИСА ДЖОНСОНА У ЯКОСТІ ПРЕМ'СР-МІНІСТРА (24 ЛИПНЯ 2019 Р.)}

\author{
Humeniuk N.H., \\ orcid.org/ 0000-0002-2275-1396 \\ Candidate of Philological Sciences, \\ Associate Professor at the Chair of English Philology and Translation \\ Borys Grinchenko Kyiv University
}

The following work is devoted to the problem of the using techniques within the Boris Johnsons' first speech as a Prime Minister of the UK, 07.24.19 to realize his speaker's purposes. The given investigation is fulfilled with the help of several methods: method of simple calculation, discourse analysis method, method of immediate constituents, pure sampling and comparative method. The Boris Johnsons' first speech as a Prime Minister of the UK is defined in the investigation as the political institutional discourse. It is assumed that Boris Johnsons uses different techniques of addressee influence with the orientation to the diverse audience. It is stressed that the technique choice greatly depends on the type of addressee: immediate communicator or potential communicator. The results of given research state that Boris Johnsons uses manipulative, argumentative, confronting, cooperative, storytelling as part of manipulative and calling to act techniques. It is pointed out that argumentative technique is realized in Boris Johnsons' speech through the usage of the argumentative blocks of information appealing to real facts, universal and national values, as well as the usage of parallel constructions and emphatic sentences. The manipulative technique is stated to be realized with the help of deictic field manipulative mechanisms. The storytelling is defined as part of manipulative technique with its separation into heroes and enemies. The confronting technique within the first Boris Johnsons' speech as a Prime Minister of the UK is assumed to be slight confrontation with some warning to the opponents of Brexit. The calling to act technique is realized through the series of appeals to act determined within the given investigation as the inner whole nation appeal to act, to change the life for better. It is stated that Boris Johnsons' speech is also oriented to the people living and working in the UK, so it is normal he uses cooperative technique to influence them All the techniques within the first Boris Johnsons' speech as a Prime Minister of the UK are known to be tactic acts of the strategic plans to influence audience. The results of given investigation presupposes perspective researches of the given techniques in details, as well as stylistic approach to the given material.

Key words: manipulative technique, argumentative technique, confronting technique, cooperative technique, storytelling, calling to act technique.

Подана робота присвячена розгляду використаних технік у першій промові Бориса Джонсона у якості Прем'єрміністра Об'єднаного Королівства від 24.07.19. із метою реалізувати свої цілі як промовця. Подане дослідження виконане з використанням певних методів: методу простого підрахунку даних, методу дискурного аналізу, методу безпосередніх даних, методу суцільної вибірки та порівняльного методу. У межах проведеного дослідження перша промова Бориса Джонсона у якості Прем'єр-міністра Об'єднаного Королівства визначається як політичний інституційний дискурс. Передбачено, що Борис Джонсон використовує різні техніки впливу на адресата з орієнтацією на різноманітну аудиторію. Підкреслено, що вибір техніки впливу значною мірою залежить від типу адресата: безпосередній чи потенційний комунікатор. Результати поданого дослідження стверджують, що Борис Джонсон використовує маніпулятивну, аргументативну, конфронтивну, кооперативну види технік, сторітелінг як частину маніпулятивної техніки та техніку заклику до дії. Зазначено, що аргументативна техніка реалізується за рахунок використання аргументативних блоків інформації, апеляції до реальних фактів, до універсальних та національних цінностей, а також за рахунок використання паралельних конструкцій та емфатичних речень. Стверджується, що маніпуля- 
тивна техніка реалізована за рахунок використання маніпулятивних механізмів із дейктичними полями. Сторітелінг визначено як частину маніпулятивної техніки з розподілом на героїв та ворогів. Конфронтивна техніка в межах першої промови Бориса Джонсона у якості Прем'єр-міністра Об'єднаного Королівства визначається як незначна конфронтація з застереженням опонентів Брекзіту. Техніка заклику до дії реалізована за рахунок використання серії закликів до дії, яка в межах проведеного дослідження визначається як внутрішній, загальнонаціональний заклик до дій, до зміни життя на краще. Стверджено, що промова Бориса Джонсона також орієнтована на людей, які живуть та працюють в Об'єднаному Королівстві, тому є нормою те, що промовець використовує кооперативну техніку впливу на них. Відомо, що всі ці техніки, використанні в першій промові Бориса Джонсона у якості Прем'єр міністра Об'єднаного Королівства, є тактичними діями його певного стратегічного плану вплинути на аудиторію. Результати поданого дослідження передбачають подальший детальний розгляд даних технік, а також стилістичний підхід до поданого матеріалу.

Ключові слова: маніпулятивна техніка, аргументивна техніка, конфронтивна техніка, кооперативна техніка, сторітелінг, техніка заклику до дії.

Introduction. Communicative approach is known to be one of the leading paradigm in the modern Linguistics and term discourse is the central part of the scientific researches $[1 ; 2 ; 3 ; 4 ; 5 ; 6 ; 7 ; 8]$. The given article is a further step of the political elite discourse investigations $[2 ; 3 ; 4 ; 6 ; 8]$ with the emphasis on the personal peculiarities of the discourse organization and realization.

The aim of the paper is to investigate the techniques of pragmatic influence within the Boris Johnsons' first speech as a Prime Minister of the UK, 07.24.19 as the ways to realize pragmacommunicative tasks of speaker. To realize the given purpose the certain methods were used within the highlighted investigation: method of immediate constituents, method of simple calculation, pure sampling and comparative method, discourse analysis method.

The material of the work. The Boris Johnsons' first speech as a Prime Minister, 07.24.19, as the political, institutional discourse

The newly coined Prime Minister of the UK and Northern Ireland, Boris Johnsons, started his speech on the 24-th of July, 2019, in the Prime Minister's Office, 10 Downing Street, after the resign of the former Prime Minister Teresa May.

His speech is known to contain the features of the institutional discourse being limited by the norms of its realization and as well as being limited in forms of its representation. These norms of language usage within the institutional discourse presuppose the appeal to the UK monarch and the analysis of the predecessor work. So, Boris Johnsons tried to avoid the usage of the direct appeal to Her Majesty the Queen, mentioning only Her name, thus, making his message more impersonal, and tried to avoid the critics to the former Cabinet with its head expressing his gratitude to her work, as his predecessor Teresa May is a member of the same party he belongs to - the Conservative one:

1. I have just been to see Her Majesty the Queen who has invited me to form a government and I have accepted.

\section{I pay tribute to the fortitude and patience of my} predecessor and her deep sense of public.

It is obvious that the UK Prime Minister first speech is similar to a presidential inauguration discourse in its purposes. Being the first appeal to the nation, the first UK Prime Minister speech belongs to the communication between the authority and society [4, p. 195], where Boris Johnson represents the authority.

As any communicative act contains both the informative and the pragmatic component, so Boris Johnsons' first speech as a Prime Minister as a certain type of discourse contains the same elements. It includes both the informative component in the form of the authority policy program and the pragmatic component in the form of speaker's intention to influence the addressee whom this message is addressed.

It is normal that Boris Johnsons' first speech as a Prime Minister includes strategic plan of the country development in the form of his Cabinet internal (to restore trust in democracy) and external policy lines (to come out of the EU on October 31 in the form of Brexit, to develop a new and exciting partnership with the rest of Europe based on free trade and mutual support), which form the informative component of it:

We are going to restore trust in our democracy and we are going to fulfil the repeated promises of parliament to the people and come out of the EU on October 31 no ifs or buts and we will do a new deal, a better deal that will maximise the opportunities of Brexit while allowing us to develop a new and exciting partnership with the rest of Europe based on free trade and mutual support.

The pragmatic component of Boris Johnsons' first speech as a Prime Minister is realized through the usage of the certain techniques and tactics. Paying attention to the fact that Boris Johnson started his message with greeting "Good afternoon" without mentioning persons of his address, we can assume that he tried to make his speech impersonal, on the one hand, and universal in its nature, on the other hand. Absence 
of the exact addressee at the beginning of his speech made it possible to enlarge the number of potential communicators within the given message a bit later, while moving through the material of the speech:

1. And so I am standing before you today to tell you the British people that those critics are wrong.

2. And next I say to our friends in Ireland, and in Brussels and around the EU...

3. ... and to all those who say we cannot be ready I say do not underestimate this country.

4. ... and the first step is to repeat unequivocally our guarantee to the $3.2 \mathrm{~m}$ EU nationals now living and working among us and I say directly to youthank you for your contribution to our society thank you for your patience and I can assure you that under this government you will get the absolute certainty of the rights to live and remain.

In this case, the given items indicate the potential communicators of Boris Johnson in his first speech as a Prime Minister:1) British people, 2) people of the EU, 3) his opponents (opponents to his vision of the country development) and 4) 3.2 million people of the EU now living and working in the UK.

So, we can state that Boris Johnson addresses British people and people living and working in the UK directly, as to the members of his communication with them, as to his listeners, addressee, using pronoun "you", and he addresses people of the EU and his opponents indirectly, as to potential communicators, as to indirect listeners, indirect addressee, whose role is limited to the role of the third persons within the given communication - "they". So, such role orientation makes it possible to show preferences and guidelines of the speaker in his communication with audience.

Argumentative techniques in Boris Johnson speech. It is known that speaker creates his / her message with the orientation to his / her potential communicators using different technics and approaches to influence them. So, Boris Johnson creates his message with the orientation to the British people using the argumentative techniques, logically starting with the characterization of the country situation as time to act and to take strong leadership:

The time has come to act, to take decisions, to give strong leadership and to change this country for the better and though the Queen has just honoured me with this extraordinary office of state.

Logically realizing his strategic intention to influence the British people Boris Johnson tries to show his readiness to serve the people:

My job is to serve you, the people because if there is one point we politicians need to remember it is that the people are our bosses.
His argumentative block is intensified by the presentation of his, as a Prime Minister, and his team future acts to change the country for better. This presentation is a plan, a program of the Cabinet real steps to make this country better. Normally, it contains the informative component as well as the pragmatic one.

The pragmatic component of his argumentative block is realized through the usage of the anaphoric parallel constructions with the emphasis on the phrase "My job is to":

1. My job is to make your streets safer - and we are going to begin with another 20,000 police on the streets and we start recruiting forthwith.

2. My job is to make sure you don't have to wait 3 weeks to see your GP and we start work this week with 20 new hospital upgrades, and ensuring that money for the NHS really does get to the front line.

3. My job is to protect you or your parents or grandparents from the fear of having to sell your home to pay for the costs of care and so I am announcing now - on the steps of Downing Street - that we will fix the crisis in social care once and for all with a clear plan we have prepared to give every older person the dignity and security they deserve.

4. My job is to make sure your kids get a superb education mwherever they are in the country and that's why we have already announced that we are going to level up per pupil funding in primary and secondary schools.

Repeated several times, the anaphoric constructions united with the emphatic sentences (that's why we have already announced that we are going to level up per pupil funding in primary and secondary schools, that is the work that begins immediately behind that black door) greatly influence Boris Johnson's listeners, addressee arresting their attention, stressing on the fact that he is ready to take leadership, that he is responsible for the future of the country:

....and that is the work that begins immediately behind that black door and though I am today building a great team of men and women I will take personal responsibility for the change I want to see.

Using the argumentative technique to influence the British people Boris Johnson appeals to the certain universal values : unity of the country, freedom, free speech, habeas corpus, democracy, as well as to the national values: national flag, inventiveness, humour, universities, scientists, armed forces, diplomacy, making people trust him and his team:

...it is time we unleashed the productive power not just of London and the South East but of every corner of England, Scotland, Wales and Northern Ireland the awesome foursome that are incarnated 
in that red white and mblue flag who together are so much more than the sum of their parts and whose brand and political personality is admired and even loved around the world for our inventiveness, for our humour, for our universities, our scientists, our armed forces, our diplomacy for the equalities on which we insist - whether race or gender or LGBT or the right of every girl in the world to 12 years of quality education and for the values we stand for around the world. Everyone knows the values that flag represents. It stands for freedom and free speech and habeas corpus and the rule of law and above all it stands for democracy and that is why we will come out of the EU on October 31 because in the end Brexit was a fundamental decision by the British people that they wanted their laws made by people that they can elect and they can remove from office and we must now respect that decision and create a new partnership with our European friends.

Moreover, within the created chain of values Brexit as the United Kingdom withdrawal from the European Union is shown to be the democratic value of the British people to elect, to create laws, to remove from the offices and to create the partnership with our European countries.

Thus, given the statute of the democratic value within the Boris Johnson's speech, Brexit as part of the external programme of the UK Parliament receives the more elevating meaning, when the most common things become more valuable, relevant and important. Such process of transforming common into special, less important into more important within the certain act of communication is able to influence the audience greatly like certain miracle, wonder.

The calling to act technique in Boris Johnson's first speech as a Prime Minister

Boris Johnson also uses the calling to act technique in his first speech as a Prime Minister. But usage of this technique is possible because of realization of the argumentative technique in his speech the audience received enough arguments to be ready to perceive his appeal to act.

The idea to act within the Boris Johnsons speech is realized through the repetition of the construction "The time to act ..." for several times: at the beginning, in the middle, at the end of his speech. It makes it possible to centrify all the information upon the urgent idea to act, to arrest addressee attention to the given problem, to etch in their memory the necessity to act:

1. The time has come to act, to take decisions to give strong leadership and to change this country for the better...
2. ...it is time we looked not at the risks but at the opportunities that are upon us...

3. It is time to change the record to recover our natural and historic role as an enterprising, outwardlooking and truly global Britain, generous in temper and engaged with the world.

Stressing on the fact that Brexit would be possible in the form of no-deal Brexit, or leaving the EU without the withdrawal agreement, Boris Johnson proposed the people of the UK to be ready for it. His proposition to be ready is not given as an appeal, as a command, it sounds rather as universal truth: everybody should be ready for it and this readiness should be active:

1. We will need to get ready at some point in the near future to come out of the EU customs union and out of regulatory control fully determined at last to take advantage of Brexit because that is the course on which this country is now set.

2. With high hearts and growing confidence we will now accelerate the work of getting ready and the ports will be ready and the banks will be ready and the factories will be ready and business will be ready and the hospitals will be ready and our amazing food and farming sector will be ready...

Moreover, we can state that the idea of active readiness is realized in the Boris Johnsons speech through the usage of parallel constructions, mentioned above, and through the usage of the polisyndeton when the conjunction "and" is repeated several times. The usage of polisyndeton makes it possible to slow down the tempo of speech and repetition "will be ready" stresses the idea of being ready that, complexly, greatly influences the audience.

Active readiness presupposes active actions. So, Boris Johnsons proposes actions using series of constructions "Let's..." known as series of appeals:

1. Let's start now to liberate the UK's extraordinary bioscience sector from anti genetic modification rules and let's develop the blight-resistant crops that will feed the world let's get going now on our own position navigation and timing satellite and earth observation systems - UK assets orbiting in space with all the long term strategic and commercial benefits for this country.

2. Let's change the tax rules to provide extra incentives to invest in capital and research and let's promote the welfare of animals that has always been so close to the hearts of the British people and yes, let's start now on those free trade deals because it is free trade that has done more than anything else to lift billions out of poverty.

The constructions of the type "Let's" are known to be commands, directives, appeals to act addressed 
to the first person plural "we", which may be determined as inner collective appeal to act, as solidarity appeal of the whole nation to act, to make positive changes, to change the country for better.

We can state that the effectiveness of the appeals to act in Boris Johnsons speech is realized complexly: through the usage of the anaphoric parallel constructions with the repetition of the initial part Let's, through the usage of the polisyndeton with the conjunction "and", through the usage of the language units with positive evaluative meaning to show the positive effect of all the steps of active actions: to liberate, extraordinary, develop, feed the world, assets, benefits, extra incentives to invest, promote, welfare, close to the hearts, free trade.

It is normal that inner appeal to act presupposes the understanding of moment to act as "now and only now", "extraordinary moment in our history":

....all this and more we can do now and only now, at this extraordinary moment in our history.

So, we can stress that appeal to act technique in the first speech of Boris Johnsons as a Prime Minister is realized complexly with the usage of series of appeals, with the usage of parallel constructions, polisyndeton, repetitions, language units with the with positive evaluative meaning.

Manipulative technique in Boris Johnson's first speech as a Prime Minister

Except the argumentative and appealing to act techniques Boris Johnson uses the manipulative technique to influence the inhabitants of the UK. The process of manipulation is concerned with the deictic fields mechanisms of layering, superpositioning and connecting [1, p. 103-140].

Deictic field is a unity of all the language signs which are grouped on one of the given axes "I/wenow - here", "You - now - there", "He/ she/ it/ they then - there", which have the semantic and pragmatic identity and fulfil the certain function within the discourse or its segments [1, p. 103].

It is known that any communicative act presupposes a set of certain communicators in it: creator of message, addressee of it and the third persons, who are not the members of given communication, but potentially may be present. The roles of the communicators are marked in any discourse by the presence of deictic fields in it: the deictic field of addressor "I/ we- now - here", the deictic field of addressee "You now - there", and the deictic field of the third persons "He/ she/ it/ they - then" [1, p. 103-105].

Within his first speech as a Prime Minister Boris Johnsons uses the mechanism of deictic field layering to differentiate the layers of the deictic field of speaker:
1) the deictic field of speaker "I-individual as a Prime Minister": (I, my, today):

.... and though I am today building a great team of men and women I will take personal responsibility for the change I want to see..

2) the deictic field of speaker "My team and I" (we, now):

We in this government will work flat out to give this country the leadership it deserves and that work begins now.

3) the deictic field of speaker "My nation and I with my team in the history of mankind" (we, our, here):

1. It is here in Britain that we are using gene therapy, for the first time, to treat the most common form of blindness here in Britain that we are leading the world in the battery technology that will help cut $\mathrm{CO} 2$ and tackle climate change and produce green jobs for the next generation ...

4. The deictic field of speaker "My nation and I with my team in the process of Brexit" (we, our, here):

1. ... as we prepare for a post-Brexit future it is time we looked not at the risks but at the opportunities that are upon us so let us begin work now to create free ports that will drive growth and thousands of high-skilled jobs in left behind areas...

The given mechanism of deictic field layering made it possible for Boris Johnson to put on different social roles: to be Prime Minister of the UK and to share personal responsibility for future of the country as a result of Brexit, to be leader of his team and to have team responsibility for it; to be an ordinary British to overcome all the difficulties of Brexit.

The mechanism of superpositioning in Boris Johnsons speech we can observe in the case of usage of the word "people", when this word belongs to different deictic fields: to the deictic field of addressee, as well as to deictic field of the addressor:

1. And so I am standing before you today to tell you the British people that those critics are wrong.

2. My job is to serve you, the people because if there is one point we politicians need to remember it is that the people are our bosses.

This manipulative technique of the deictic fields superpositioning makes it possible for Boris Johnsons to manipulate the consciousness of the UK inhabitants, showing that addressor belongs to the sphere of addressee, that addressor is part of addressee, that they have something in common, that role of addressee in the sphere of addressor is great.

But it is pure manipulation. In reality, it is vice versa. Ordinary people are dependent on the political elite of the country, the level of their well-being coordinately diverses from the well-being of their 
state elite. So, not ordinary people, but political elite is bosses of ordinary people.

In his first speech as a Prime Minister Boris Johnsons uses the universal deictic field, represented by the pronouns no one:

No one in the last few centuries has succeeded in betting against the pluck and nerve and ambition of this country.

It is known that the universal deictic field is able to change the roles of the communicators making them equal to certain ideas. "No one" in this case means addressor, addressee and the third persons as well.

So, the manipulating technique in the speech of Boris Johnsons is realized within the mechanisms of deictic field manipulation.

Storytelling technique in Boris Johnson speech

The first speech of Boris Johnson as a Prime Minister has all the peculiarities of narrative. The given speech has the narrative structure: the introduction, the main body and the end.

The introduction contains the information about Teresa May resign and Boris Johnsons appointment of a Prime Minister. The main body is centralized to the problem of Brexit. The end of narrative is optimistic.

The events in the speech of Boris Johnsons are given through the first person singular presentation, it is the story of the newly coined Prime Minister of the UK.

Moreover, it is a story of conflict, which contains the main characters: heroes and enemies. According to Boris Johnsons vision, his nation with his team and himself are the main heroes of his story struggling with Brexit opponents for their democratic values. Heroes have the great potential to fight their enemies. The end of this story is hopeful in future perspective, it resembles happy end of fairy tale.

We can state that the story telling technique within the Boris Johnsons speech is a part of manipulative technique, when the vision of the addressor of information is given as some kind of truth, as real fact, when the separation into enemies and heroes is doubtly relevant, because opponents to somebody's position don't mean enemy to the whole nation. Moreover, opponents are necessary to move ahead, to see strong and weak points, to find the best ways of problem solution.

Confronting technique in Boris Johnson's first speech as a Prime Minister

Boris Johnsons uses confronting technique to the opponents of his and his team vision of Brexit. This confrontation is given in indirect way, as to persons, who are not his communicators, but may be present in this communication - they. As the rules of communication allow to use the language units with the negative evaluative meaning toward the noncommunicative persons, so Boris Johnsons uses them to characterize his opponents:

1. And so I am standing before you today to tell you the British people that those critics are wrong.

2. The doubters, the doomsters, the gloomsters they are going to get it wrong again.

3. The people who bet against Britain are going to lose their shirts.

We can state that this type of confrontation given in indirect way is known to be slight confrontation. The results of given investigation show that this slight confrontation is gradually increasing in Boris Johnsons speech up to warning, even threat, to the opponents of Brexit, when he addresses them as his addressee, using command, directive:

... and to all those who say we cannot be ready I say do not underestimate this country. Do not underestimate our powers of organisation and our determination because we know the enormous strengths of this economy in life sciences, in tech, in academia, in music, the arts, culture, financial services..

The warning to the opponents of Brexit within the Boris Johnsons speech is transformed into the universal truth at the end of it. So, it sounds rather categorical and without any doubts:

No one in the last few centuries has succeeded in betting against the pluck and nerve and ambition of this country. They will not succeed today.

So, we can assume that Boris Johnsons uses technique of slight, indirect confrontation to his opponents in the first speech as a Prime Minister to show himself be ready to fight, as well as be ready to avoid fighting.

Cooperative technique in Boris Johnson speech as a Prime Minister

Boris Johnsons' speech is also oriented to the people living and working in the UK. He addressed them "you" as to his direct communicators expressing his gratitude for their work in the UK and their contribution for the society:

and I say directly to you - thank you for your contribution to our society thank you for your patience and I can assure you that under this government you will get the absolute certainty of the rights to live and remain...

In this case, Boris Johnsons uses cooperative technique, orienting to cooperation with them. They are not citizens of the UK, they have no rights to influence the political life of the country by voting, but as the potential force they may change the real situation in the country. So, Boris Johnsons tries to show readiness of his team to guarantee them worthy life 
and calmness and order in the society life of the UK in general.

Boris Johnsons uses the same cooperative technique for "our friends in Ireland, and in Brussels and around the EU":

And next I say to our friends in Ireland, and in Brussels and around the EU.

I am convinced that we can do a deal without checks at the Irish border, because we refuse under any circumstances to have such checks and yet without that anti-democratic backstop and it is of course vital at the same time that we prepare for the remote possibility that Brussels refuses any further to negotiate.

It is known that there is some conflict of interests between the government of the UK and the EU in regard of Brexit. This conflict of interests is marked in his speech by the usage of the language units of the negative evaluative meaning: refuse, anti-dem- ocratic backstop. But Boris Johnsons tries to avoid the conflict situation showing his team orientation to cooperate with the EU by using the language units of positive evaluative meaning: friends, vital, possibility, to negotiate, as well as by using deictic marker "our" to show the EU partners as the important part of his team policy.

\section{Conclusions}

Summing up the material, we can state that Boris Johnsons uses different techniques to influence his audience, to achieve his pragmatic purposes in the first speech as a Prime Minister: argumentative, manipulative, confronting, appealing to act, cooperative technique and storytelling as part of manipulative one.

All these techniques need more detailed observation, as well as the problems of stylistic aspect investigation within the Boris Johnsons first speech as a Prime Minister.

\section{REFERENCES:}

1. Гуменюк Н.Г. Дейктические маркеры как фактор влияющий на реализацию категории оценки (на материале англоязычной прессы и рекламы) : дисс. ...канд. филол. наук : 10.03.04. Киев, 1996. 167 с.

2. Гуменюк Н.Г. Англомовний дискурс П. Порошенка : синтаксично-стилістичний аспент (на матеріалі звернення до Конгресу США від 23.12.15). Мови професійної комунікації: лінгвокультурний, когнітивно-дискурсивний, перекладознавчий та методичний аспекти : матеріали III Міжнародної науково-практичної конфе-ренції, 21 квітня 2016 р., НТУУ «КПІ». Київ : Кафедра. С. 35-37.

3. Гуменюк Н.Г. Політичний дискурс Б. Обами : синтаксично-стилістичний аспект (на матеріалі звернення до нації з питань Сирії, від 10.09.12). Мови професійної комуніукації: лінгвокультурний, когнітивно-дискурсивний, перекладознавчий та методичний аспекти : матеріали I Міжнародної науково-практичної конференції, 2014 р., НТУУ “КПІ". Київ : Кафедра, 2014 р. С. 37-39.

4. Петлюрченко Н.В. Харизматика: мовна особистість, її дискурс : монографрія. Одеса, 2009. 464 c.

5. Почепцов Г.Г. Від facebooky до гламуру до Wikileaks: медіакомунікації : монографія. Київ : Спадщина, 2014. $464 \mathrm{c}$.

6. Славова Л.Л. Мовна особистість політика : когнітивно-дискурсивний аспект : монографія. Житомир : Вид-во ЖДУ ім. І. Франка, 2010. 358 с.

7. Чудинов А.П. Россия в метафорическом зеркале: когнитивное исследование политической метафоры (1991-2000). Екатеринбург, 2001. 238 с.

8. Slavova L.L. Image of a Leader's Linguistic Personality in Political Discourse. Cognition, Communication, Discourse. 2015. № 11. P. 109-122. 